\title{
Ozonized water used as complementary therapy for stomatitis in Salvator merianae -
}

\section{case report}

Água ozonizada usada como terapia complementar para estomatite em Salvator merianae - relato

de caso

Agua ozonizada utilizada como terapia complementaria para la estomatitis en Salvator merianae reporte de caso

Lucas Micael Freire Pereira

ORCID: https://orcid.org/0000-0003-4071-4203 Universidade Federal Rural do Semi-Árido, Brazil E-mail: lucasmicaelfp@gmail.com

Fabiano Rocha Prazeres Júnior

ORCID: https://orcid.org/0000-0002-4002-7334

Universidade Federal de Sergipe, Brazil E-mail: fabiano_357@hotmail.com

João Vitor de Oliveira Gurgel

ORCID: https://orcid.org/0000-0003-4020-6583 Universidade Federal Rural do Semi-Árido, Brazil

E-mail: joaovitoroliveiragurgel@ hotmail.com

Vanessa Silva Santana

ORCID: https://orcid.org/0000-0003-3405-6582 Universidade Federal Rural do Semi-Árido, Brazil E-mail: vanessa.mev@hotmail.com

Leonardo Lomba Mayer

ORCID: https://orcid.org/0000-0003-1023-2043 Universidade Federal Rural do Semi-Árido, Brazil E-mail: leonardomayer@id.uff.br

Arickson Wesley da Silva Pereira ORCID: https://orcid.org/0000-0003-1995-9919 Universidade Federal Rural do Semi-Árido, Brazil E-mail: aricksonsrv13@hotmail.com

Nayara Oliveira de Medeiros

ORCID: https://orcid.org/0000-0001-9357-5628

Universidade Federal Rural do Semi-Árido, Brazil

E-mail: nayara.oliveira.medvet@hotmail.com

Amanda de Carvalho Moreira

ORCID: https://orcid.org/0000-0003-0471-1208

Universidade Federal Rural do Semi-Árido, Brazil

E-mail: amandacmvet@gmail.com

Carlos Iberê Alves Freitas

ORCID: https://orcid.org/0000-0003-0859-3528

Universidade Federal Rural do Semi-Árido, Brazil

E-mail: ibere@ufersa.edu.br

\begin{abstract}
The Argentine black and white tegu (Salvator merianae) is a reptile belonging to the family Teiidae. Compared with other families, teiids are morphologically similar. However, their sizes vary considerably, with $S$. merianae being the largest endemic lizard in South America. The characteristics, habitat, and habits of $S$. merianae need to be investigated, to provide adequate ex situ adaptation opportunities and avoid accidents in the pet industry. One advancing complementary therapy is the use of ozone, which has potent antimicrobial action when applied topically, due to the oxidizing and healing effects resulting from the stimulation of tissue cell proliferation and remodeling. To generate information concerning ozone therapy, the treatment of stomatitis caused by Portland cement in an Argentine black and white tegu using ozonized water as a complementary therapy is reported. Fluid and antibiotic therapies (enrofloxacin, butorphanol, meloxicam, and sucralfate) were introduced, along with the daily rinsing of the oral cavity with freshly prepared ozonized water. No toxic effects relating to ozone use were observed, and its topical use as a complementary therapy proved to be low cost and highly efficient. These findings demonstrate the need to obtain knowledge concerning this therapy and promote its use in wild animals.
\end{abstract}


Keywords: Reptiles; Ozone; Cement.

\begin{abstract}
Resumo
O teiú-comum (Salvator merianae) é um réptil pertencente à família Teiidae. Comparados com outras famílias, os teídeos são morfologicamente semelhantes. No entanto, seus tamanhos variam consideravelmente, sendo S. merianae o maior lagarto endêmico da América do Sul. As características, habitat e hábitos de $S$. merianae precisam ser investigados, para fornecer oportunidades adequadas de adaptação ex-situ e evitar acidentes na indústria pet. Uma terapia complementar em avanço é o uso do ozônio, que possui potente ação antimicrobiana quando aplicado topicamente, devido aos efeitos oxidantes e cicatrizantes decorrentes da estimulação da proliferação e remodelação celular tecidual. Para o desenvolvimento de informações sobre a ozonioterapia, é relatado o tratamento da estomatite causada pelo cimento Portland em um teiú utilizando água ozonizada como terapia complementar. Fluidos e antibióticos (enrofloxacina, butorfanol, meloxicam e sucralfato) foram introduzidos, juntamente com o enxágue diário da cavidade oral com água ozonizada recém-preparada. Não foram observados efeitos tóxicos relacionados ao uso do ozônio, e seu uso tópico como terapia complementar mostrou-se de baixo custo e altamente eficiente. Esses achados demonstram a necessidade de se obter conhecimentos sobre essa terapia e promover seu uso em animais silvestres. Palavras-chave: Répteis; Ozônio; Cimento.
\end{abstract}

\title{
Resumen
}

El tegu blanco y negro (Salvator merianae) es un reptil perteneciente a la familia Teiidae. En comparación con otras familias, los teiids son morfológicamente similares. Sin embargo, sus tamaños varían considerablemente, siendo $S$. merianae el lagarto endémico más grande de América del Sur. Es necesario investigar las características, el hábitat y los hábitos de $S$. merianae para brindar oportunidades adecuadas de adaptación ex-situ y evitar accidentes en la industria de las mascotas. Una terapia complementaria avanzada es el uso de ozono, que tiene una potente acción antimicrobiana cuando se aplica tópicamente, debido a los efectos oxidantes y curativos que resultan de la estimulación de la proliferación y remodelación de las células tisulares. Para generar información sobre ozonoterapia, se reporta el tratamiento de la estomatitis por cemento Portland en un tegu utilizando agua ozonizada como terapia complementaria. Se introdujeron terapias con líquidos y antibióticos (enrofloxacina, butorfanol, meloxicam y sucralfato), junto con el enjuague diario de la cavidad oral con agua ozonizada recién preparada. No se observaron efectos tóxicos relacionados con el uso de ozono y su uso tópico como terapia complementaria resultó ser de bajo costo y altamente eficiente. Estos hallazgos demuestran la necesidad de obtener conocimientos sobre esta terapia y promover su uso en animales salvajes.

Palabras clave: Reptiles; Ozono; Cemento.

\section{Introduction}

The Argentine black and white tegu (Salvator merianae) is a reptile belonging to the order Squamata and family Teiidae. Compared with other families, teiids are highly morphologically similar to each other. Almost all species have an elongated slender body, with whip-shaped tails, and heads ending in narrow snouts. However, size within the family varies considerably (Vitt et al, 2000), with the Argentine black and white tegu being the largest endemic lizard in South America, reaching $160 \mathrm{~cm}$ in total length and weighing up to $5 \mathrm{~kg}$ (Cechin et al, 2011). They are omnivorous and opportunistic foragers with daytime habits that feed on vegetables, fruits, insects, small vertebrates, and even carcasses (Vieira, 2016).

The inflammatory process of the oral cavity, known as stomatitis, in reptiles is characterized by having several predisposing factors as primary sources, including nutritional deficiencies, unhealthy management, poorly executed physical containment, and preexisting viral infections. All of these predispose the animals to opportunistic infections, which is a worrisome factor when treating reptiles (Draper et al, 1981; Hedley, 2016; Pereira et al, 2017; Martins et al, 2021). However, stomatitis can also be caused by the ingestion of irritants, such as Portland cement, because of its alkaline, hygroscopic, and abrasive properties are often associated with occupational dermatitis (Bedoya-Marrugo et al, 2017; Leon-Kabamba et al, 2018).

Portland cement is a fine powder with binding properties due to its chemical composition, resulting from the combination of raw materials (limestone and clay) calcined inside furnaces. This mainly generates silicates, aluminates, iron, and calcium aluminates. Portland cement hardens under the action of water, reaching a $\mathrm{pH}$ greater than 12 , which is a highly alkaline $\mathrm{pH}$, making the cement more irritating to the skin due to its hygroscopic and abrasive properties. When Portland 
cement remains under pressure, friction, or occlusion for a long time and is in contact with the skin, this can cause anything from mild to severe irritant contact dermatitis (Alchorne et al, 2010; Pugliesi, 2018; Leon-Kabamba et al, 2018)

This oral inflammation, either caused by microorganisms or by irritants, requires special attention concerning the treatment of choice, as systemic topical drugs and complementary therapies need to be combined to achieve the complete recovery of the patient. One of the complementary therapies that has been growing in human and veterinary medicine, is the use of ozone, which when applied topically has potent antimicrobial action due to the oxidizing and healing effects resulting from the stimulation of the proliferation and remodeling of tissue cells. Given its low cost and minimal side effects, it is a viable option in most clinical situations (Bocci, 2005; Smith et al, 2017, Zeng \& Lu, 2018; Suh et al, 2019).

As the Argentine black and white tegu has been introduced into the pet industry, their characteristics, habitat, and habits need to be investigated, seeking to provide adequate ex situ adaptation opportunities, thus avoiding the occurrence of accidents. An animal that is not adapted to the enclosure where it lives can become agitated and look for ways to escape from the environment, potentially putting the animal in a situation where it can get hurt or come into contact with toxic substances, putting its health at risk.

To generate information concerning the use of ozone therapy in these animals, this study reports on the treatment of stomatitis caused by Portland cement in an Argentine black and white tegu (Salvator merianae) using ozonized water as a complementary therapy.

\section{Methodology}

\section{Clinical Presentation and Management}

A one-year-old male Argentine black and white tegu (Salvator merianae) weighing $1 \mathrm{~kg}$ arrived at the Medical and Surgical Clinic of Wild Animals, at the Jerônimo Dix-Huit Rosado Maia Veterinary Hospital - HOVET, of the Federal Rural University of the Semi-Arid Region (UFERSA), on May 21, 2019. The tutor reported that the animal was suffering from anorexia and had fled four days ago from the terrarium where it lived with a female of the same species, after which it showed these clinical signs. During the anamnesis, the tutor also reported that the animal was found the day before inside a bag of cement.

At the physical examination, the animal was slightly apathetic, with a good body score. Remnants of Portland cement, sialorrhea, gingivitis, ulcerative lesions, and plaques with caseous material in the lateral commissures and palate were observed while evaluating its oral cavity (Figure 1A), characterizing a severe picture of stomatitis. Radiographic examinations and ultrasounds were requested for a complete evaluation of the gastrointestinal tract, looking for solid aggregates or mucosal lesions due to substance ingestion. However, no relevant changes were observed in either examination.

The established therapeutic protocol included enrofloxacin ( $5 \mathrm{mg} / \mathrm{kg}$, IM, SID, 10 days), butorphanol (0.05 mg/kg, IM, SID, 3 days), meloxicam ( $0.2 \mathrm{mg} / \mathrm{kg}$, SC, QOD, 3 days), sucralfate ( $600 \mathrm{mg} / \mathrm{kg}$, VO, TID, 10 days), fluid therapy (Ringer lactate $15 \mathrm{~mL} / \mathrm{kg}$, SC, BID, 10 days), and using a $20 \mathrm{~mL}$ syringe to rinse the oral cavity with jets of freshly prepared ozonized water (40 $\mu \mathrm{g} / \mathrm{mL}$, SID, 10 days). A significant improvement in health was observed after 3 days (D3) from the start of treatment (Figure 1B). Spontaneous feeding occurred on D9, with the animal receiving medical discharge and showing the complete healing of the oral mucosa (Figure 1C) after 10 days of treatment (D10). 
Figure 1. Tegu oral cavity lesions. 1A - Ulcerative lesions (star) and plaques with caseous material in the lateral commissure and palate (arrows). 1B - Oral cavity after 3 days of treatment (D3). 1C - Oral cavity after 10 days of treatment (D10).
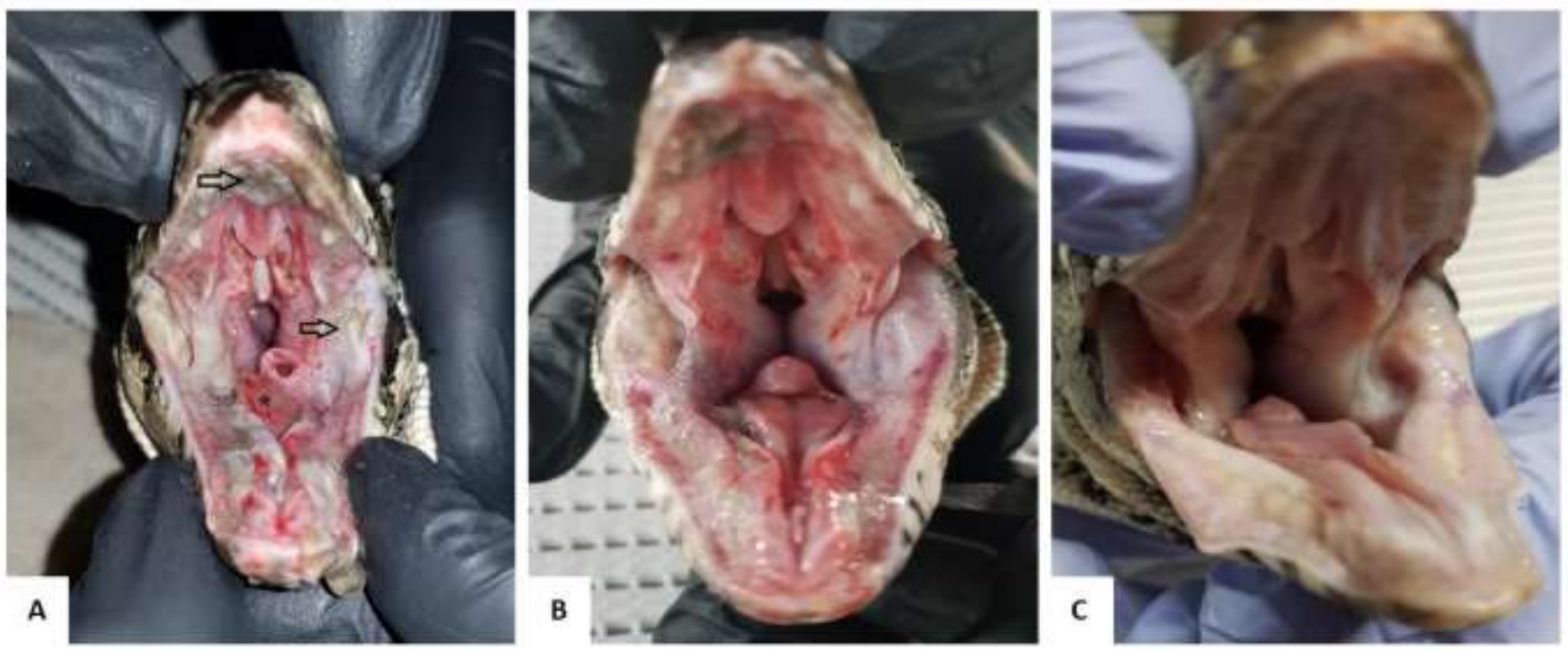

Source: Authors (2019).

\section{Results and Discussion}

In the present case, a management error allowed the escape of an animal that eventually came into contact with a caustic material, causing the emergence of ulcerative stomatitis, which reinforces the importance of ensuring adequate nutrition and enclosure for reptiles bred in captivity. Improper enclosures are one of the common causes for the occurrence of diseases (Divers \& Stahl, 2018). Moreover, adaptation is necessary to avoid accidents, as previously mentioned.

Throughout the treatment, the patient recovered rapidly with a visible regression of the lesions from the third day, with complete healing after 10 days. Faster results were obtained here when compared to Arruda (2012), in which a green iguana (Iguana iguana) with mild stomatitis was treated with a similar protocol, but without ozonized water, and achieved complete healing after 15 days of treatment.

The oral microbiota of lizards is composed mainly of Gram-negative bacteria, such as Pseudomonas, Proteus and Aeromonas (Hedley, 2016; Tian et al, 2020). According to Oliveira and Dias (2012), among the main causes of delayed healing are local bacterial infections, perfusion, and deficient oxygenation (Sanchez, 2008; Gantwerker \& Hom, 2012). The bactericidal action attributed to ozone (Penido et al, 2010; Chagas \& Mira, 2015; Santana et al, 2018) and its proven action on blood fluidity, decreasing its viscosity by decreasing macromolecules and clot formation (Van Der Zee \& De Monte, 2001), contributed to the control and reduction of these conditions and consequently to the improved recovery of the animal.

Ozone is widely recognized as one of the best antibacterial, antiviral, and antifungal agents, and therefore is an important alternative when it comes to multi-resistant bacterial infections, such as those commonly associated with reptile stomatitis (Valacchi et al, 2005; Martins et al, 2021). It is commonly used topically to treat anaerobic infections, abscesses, gingivitis, fistulas, decubitus ulcers, and burns (Valacchi et al, 2005; Zang \& Lu, 2018). Although ozone use in reptiles is scarcely documented, the use of ozone to treat spondylitis caused by Salmonella sp. has been reported in Boa constrictor, obtaining significant results (Hardt et al, 2017).

In a recent experimental study, which was the first to evaluate ozone therapy in the healing of dermal lesions in reptiles, ozonized sunflower oil was shown to be effective in increasing the inflammatory response and formation of granulation tissue in experimentally induced wounds in Trachemys scripta elegans (Ginel et al, 2021). The results showed an 
increase in the presence of leukocyte cells, fibroblast proliferation, and early collagen fibre remodeling compared to the control group. Although the testudines do not have an effective capacity to contract wounds in centripetal motion, due to the absence of cutaneous muscles, wounds treated with ozone had a statistically greater decrease in diameter than those not treated (Ginel et al, 2021). Similar studies and case reports involving humans and other mammals are recurrent; however, in reptiles, they are still scarce (Fitzpatrick et al, 2018; Sciorsci et al, 2020; Ginel et al, 2021).

No toxic effects relating to the use of ozone were observed during therapy. As these effects are usually associated with the volume, concentration, and inadequate routes of administration. Ozone should only be applied by trained professionals to avoid risks to the patient and the loss of therapy credibility (Bocci, 2005).

\section{Conclusion}

The topical use of ozonized water as complementary therapy proved to be a low-cost alternative for the treatment of stomatitis in reptiles. Although there is only one study involving this class and few case reports, the findings of this work demonstrated that ozonized water was effective as a complementary therapy for stomatitis in a Salvator merianae, and although researchers are interested in the subject, and potentiality of this therapy, it is still necessary to carry out more research and, consequently, the promotion of its use in reptiles.

\section{References}

Alchorne, A. D. O. D. A., Alchorne, M. M. D. A., \& Silva, M. M. (2010). Dermatoses ocupacionais. Anais brasileiros de dermatologia, 85, 137-147. 10.1590/S0365-05962010000200003

Arruda D. R., Couto, E. P., Pinto, D. G., \& Mikail, S. (2012). Estomatite em Iguana Verde (Iguana iguana): Relato de Caso. Anais do XV Congresso e XXI Encontro da Associação Brasileira de Veterinários de Animais Selvagens, 06-09.

Bedoya-Marrugo, E. A., Severiche-Sierra, C. A., Sierra-Calderon, D. D., Jaimes-Morales, J., Marrugo-Ligardo, Y. A., \& Espinosa-Fuentes, E. A. (2017). Conditions of work and dermatitis in workers exposed to chemical risks by cement. International Journal of Applied Engineering Research, 12(22), 1211912126.

Bocci, V. (2005). Ozone A new medical drug. Dordrecht: Springer

Cechin, S. Z., Winck, G. R., \& Blanco, C. C. (2011). Population ecology of Tupinambis merianae (Squamata, Teiidae): home-range, activity and space use. Animal Biology, 61(4), 493-510. 10.1163/157075511X59764

Chagas, L. H., \& Mira, A. (2015). Efeito do óleo ozonizado em lesões cutâneas em ratos. Revista Cultivando o Saber, $160-172$.

Divers, S. J., \& Stahl, S. J. (Eds.). (2018). Mader's Reptile and Amphibian Medicine and Surgery-E-Book. Elsevier Health Sciences.

Draper, C. S., Walker, R. D., \& Lawler, H. E. (1981). Patterns of oral bacterial infection in captive snakes. Journal of the American Veterinary Medical Association, 179(11), 1223-1226.

Fitzpatrick, E., Holland, O. J., \& Vanderlelie, J. J. (2018). Ozone therapy for the treatment of chronic wounds: A systematic review. International wound journal, 15(4), 633-644. 10.1111/iwj.12907

Gantwerker, E. A., \& Hom, D. B. (2012). Skin: histology and physiology of wound healing. Clinics in plastic surgery, 39(1), 85-97. 10.1016/j.cps.2011.09.005

Ginel, P. J., Negrini, J., Guerra, R., Lucena, R., Ruiz-Campillo, M. T., \& Mozos, E. (2021). Effect of topical ozonated sunflower oil on second intention wound healing in turtles: a randomised experimental study. Journal of Veterinary Science, 22(2). 10.4142/jvs.2021.22.e27

Hardt, I., Gava, M. G., Paz, J. S., Silva, E. L., Souza, T. D., Jabour, F. F., \& Flecher, M. C. (2017). Doença do corpúsculo de inclusão e espondilite por Salmonella sp. em uma Boa constrictor constrictor. Pesquisa Veterinária Brasileira, 37, 984-990. 10.1590/s0100-736x2017000900014

Hedley, J. (2016). Anatomy and disorders of the oral cavity of reptiles and amphibians. Veterinary Clinics of North America: Small Animal Practice, 19(3), $689-706$.

Leon-Kabamba, N., Kakoma, S. J. B., Oscar-Luboya, N., Pascal-Kimba, M., Banza-Lubamba, N. C., Ngatu, N. R., \& Nemery, B. (2018). Occupational cement dermatitis and cement burns. In Occupational and Environmental Skin Disorders (pp. 63-69). Springer, Singapore. 10.1007/978-981-10-8758-5_6

Martins, N. B., Ferreira, L. A. R., Queiroz, C. L., Buiatte, A. B. G., Lima, A. M. C., de Souza, R. R., \& Santos, A. L. Q. (2021). Caseous Stomatitis Caused by Pseudomonas aeruginosa in Boa constrictor amarali. Acta Scientiae Veterinariae, 49. 10.22456/1679-9216.105257 
Research, Society and Development, v. 10, n. 11, e280101119550, 2021

(CC BY 4.0) | ISSN 2525-3409 | DOI: http://dx.doi.org/10.33448/rsd-v10i11.19550

Oliveira, I. V. P. M, Dias, R. V. C. (2012). Cicatrização de feridas: fases e fatores de influência. Acta Veterinária Brasílica, 6(4): 267-271. 10.21708/avb.2012.6.4.2959

Penido, B. R., de Aguiar Lima, C., \& Ferreira, L. F. L. (2010). Aplicações da ozonioterapia na clínica veterinária. Pubvet, 4, Art-974.

Pereira, H. C., Gomes, D. O., Hirano, L. Q. L., Santos, A. L. Q., \& Lima, A. M. C. (2017). Oral microbiota in healthy Bothrops atrox (Serpentes: Viperidae) and in snakes with stomatitis. Acta Veterinaria Brasilica, 11(3), 180-183. 10.21708/avb.2017.11.0.7157

Pugliesi, N. (2018). Cimento: diferentes tipos e aplicações (Associação Brasileira de Cimento Portland) https://abcp.org.br/cimento-diferentes-tipos-eaplicacoes/.

Sanchez, C. M. S. (2008). A utilização do óleo ozonizado para o tratamento tópico de lesões em porquinho da índia (Cavia porcellus)-relato de caso. Monografia do Curso de Especialização em Clínica Médica e Cirúrgica e Animais Selvagens da Universidade Camilo Castelo Branco, Itatiba, SP.

Santana V.S., Prazeres Júnior F.R., Mayer L.L., Almeida, G. F. O., Pereira, L. M. F., Rocha, E. L. B., \& de Souza Jucá, M. A. (2018). Uso de óleo de girassol ozonizado para cicatrização de ferida cirúrgica necrosada em (Oryctolagus cuniculus) - Relato de caso. Anais do IX Encontro Nordestino de Grupos de Estudos de Animais Selvagens, 20.

Sciorsci, R. L., Lillo, E., Occhiogrosso, L., \& Rizzo, A. (2020). Ozone therapy in veterinary medicine: a review. Research in veterinary science, $130,240-246$. 10.1016/j.rvsc.2020.03.026

Smith, N. L., Wilson, A. L., Gandhi, J., Vatsia, S., \& Khan, S. A. (2017). Ozone therapy: an overview of pharmacodynamics, current research, and clinical utility. Medical gas research, 7(3), 212. 10.4103/2045-9912.215752

Suh, Y., Patel, S., Kaitlyn, R., Gandhi, J., Joshi, G., Smith, N. L., \& Khan, S. A. (2019). Clinical utility of ozone therapy in dental and oral medicine. Medical gas research, 9(3), 163. 10.4103/2045-9912.266997

Tian, Z., Gou, D., Wu, Y., \& Guo, P. (2020). Gut and oral bacterial diversity of the lizard Diploderma splendidum investigated using metagenomic analysis. 10.21203/rs.3.rs-128688/v1

Valacchi, G., Fortino, V., \& Bocci, V. (2005). The dual action of ozone on the skin. British Journal of Dermatology, 153(6), 1096-1100. 10.1111/j.13652133.2005.06939.x

Van Der Zee, H., \& De Monte, A. (2001). Ozone auto-haemotherapy in lower limb ulcerations. In Proceedings of the 15th Ozone World Congress. London: Speedprint MacMedia Ltd (London), 148-157.

Vieira R.C. (2016). História natural, ecologia populacional e genética de Salvator merianae (Duméril \& Bibron, 1839) (Squamata, Teiidae) no sul do Brasil [tese]. Programa de Pós-Graduação em Biologia Animal: Instituto de Biociências da Universidade Federal do Rio Grande do Sul.

Vitt, L. J., Sartorius, S. S., Avila-Pires, T. C. S., Esposito, M. C., \& Miles, D. B. (2000). Niche segregation among sympatric Amazonian teiid lizards. Oecologia, 122(3), 410-420. 10.1007/s004420050047

Zeng, J., \& Lu, J. (2018). Mechanisms of action involved in ozone-therapy in skin diseases. International immunopharmacology, 56, $235-241$. 10.1016/j.intimp.2018.01.040 